\title{
ROLE OF THE STATE IN AGRICULTURAL DEVELOPMENT
}

\author{
Natalya V. Gorshkova \\ Volgograd State University, Volgograd,Russian Federation \\ Ekaterina A. Shkarupa \\ Volgograd State University, Volgograd,Russian Federation \\ Aleksandr S. Rulev \\ Volgograd State University, Volgograd, Russian Federation
}

\begin{abstract}
The peculiarities of agriculture, which require the creation of conditions for its development, retain the importance of the role of the state in supporting the industry. The need for such participation is reinforced by the latest trends in economy. Export orientation, digitalization, the coronavirus pandemic reinforce the political and economic causes of state intervention. The purpose of this work is to consider key methods and priorities of state support for agriculture and the possibility of their improvement and expansion under the influence of new requirements. Having studied the mechanism of concessional lending to agriculture, it was concluded that it was effective and identified some problems that served as a basis for identifying opportunities for its further improvement. It was concluded that the state plays a dominant role in the development of small forms of agribusiness and the expansion of agricultural export potential. The unique features of the COVID-19 pandemic, which faced not only the world but also Russian economy, have opened up opportunities and created threats to agricultural development. The coronavirus pandemic has given a powerful impetus to the massive introduction of digital technologies. The article considers possible directions of developing methods and directions of state participation in agriculture.

Key words: agriculture, state support, exports, digitalization, COVID-19 pandemic, subsidies, concessional lending, grants.

Citation. Gorshkova N.V., Shkarupa E.A., Rulev A.S. Role of the State in Agricultural Development. Journal of Volgograd State University. Economics, 2020, vol. 22, no. 2, pp. 171-181. (in Russian). DOI: https://doi.org/ 10.15688/ek.jvolsu.2020.2.16
\end{abstract}

УДК 338.43

ㅇ ББК 65.32-21
Дата поступления статьи: 30.04.2020

Дата принятия статьи: 18.05.2020

\section{РОЛЬ ГОСУДАРСТВА В РАЗВИТИИ СЕЛЬСКОГО ХОЗЯЙСТВА}

\section{Наталья Валерьевна Горшкова}

Волгоградский государственный университет, г. Волгоград, Российская Федерация

\section{Екатерина Александровна Шкарупа}

Волгоградский государственный университет, г. Волгоград, Российская Федерация

\section{Александр Сергеевич Рулев}

Волгоградский государственный университет, г. Волгоград, Российская Федерация

Аннотация. Особенности сельского хозяйства, требующие создания условий для его развития, сохраняют значимость роли государства в поддержке отрасли. Необходимость такого участия диктуется последними трендами, происходящими в экономике. Ориентация на экспорт, цифровизация, пандемия короновирус- 
ной инфекции усиливают политические и экономические причины вмешательства государства. Целью данной работы является рассмотрение ключевых методов и приоритетных направлений государственной поддержки сельского хозяйства, возможности их совершенствования и расширения под влиянием новых требований. Анализ механизма льготного кредитования сельского хозяйства позволил сделать вывод о его эффективности и обозначить некоторые проблемы, выступившие базисом для выявления возможностей его дальнейшего совершенствования, а также доминирующей роли государства в развитии малых форм агробизнеса и расширении экспортного потенциала сельского хозяйства. Уникальные особенности пандемии COVID-19, с которой столкнулась мировая в целом и российская экономика в частности раскрыла возможности и создала угрозы для развития сельского хозяйства. Кроме того, она дала мощный импульс массовому внедрению цифровых технологий.

Ключевые слова: сельское хозяйство, государственная поддержка, экспорт, цифровизация, пандемия COVID-19, субсидирование, льготное кредитование, гранты.

Цитирование. Горшкова Н. В., Шкарупа Е. А., Рулев А. С. Роль государства в развитии сельского хозяйства // Вестник Волгоградского государственного университета. Экономика. -2020. - Т. 22, № 2. - C. 171-181. -DOI: https://doi.org/10.15688/ek.jvolsu.2020.2.16

\section{Введение}

Президент Владимир Путин отметил, что «российский АПК вышел на опережающие темпы развития и укрепляет позиции как современная, высокотехнологичная отрасль с хорошим потенциалом качественного роста. При этом важно сохранить набранную динамику в отрасли, обеспечить внутренний рынок и использовать те возможности, которые открываются для экспорта продовольствия» [Совещание о ситуации ...].

На наш взгляд, актуальным представляется изучение методов и направлений государственной поддержки сельского хозяйства, а также возможности их совершенствования и расширения под влиянием новых требований.

\section{Направления и методы государственной поддержки сельского хозяйства}

Существовавшая с 2017 г. «единая субсидия» дестабилизировала условия деятельности сельскохозяйственных товаропроизводителей. Консолидация субсидии (действующие до этого разрозненно 54 субсидии были объединены в 7 направлений для субсидирования), преследовавшая цель создания простой и прозрачной системы выдачи денежных средств, не была достигнута. Так, в некоторых регионах эта поддержка или не осуществлялась совсем, или осуществлялась по остаточному принципу. Невозможность ее адаптации и укрепления в системе государственной поддержки сельскохозяйственной отрасли определила необходимость нового подхода.
В 2020 г. результатом изменения субсидирования стала трансформация единой субсидии и выделение компенсирующей и стимулирующей субсидии. Так называемый механизм регионализации государственной поддержки дает возможность самостоятельного выбора приоритетов в сельском хозяйстве, стимулируя при этом точки ростра отрасли и развивая наиболее перспективные направления [Минпромторг России ...].

Поддержка сельскохозяйственного производства по отдельным отраслям растениеводства и животноводства осуществляется посредством получения компенсирующей субсидии, предполагает предоставление бюджетных ассигнований на поддержание доходности сельскохозяйственных товаропроизводителей (компенсация выпадающих доходов).

Компенсирующая субсидия предоставляется 84 регионам России. Основой ее формирования служат ретроспективные данные регионов, исходящие из доли каждого региона в общем значении показателей по стране. Объем средств, выделенных на эти цели в 2020 г., равен 34,2 млрд руб. [Распределение субсидий ...].

Стимулирующая субсидия направляется регионам, выбравшим приоритетные отрасли, которые станут базисом развития сельскохозяйственного производства. Целевые получатели такой субсидии представлены сельскохозяйственными товаропроизводителями (за исключением граждан, ведущих личное подсобное хозяйство, и сельскохозяйственных кредитных потребительских кооперативов) научными и образовательными организациями. Последние в процессе научной, научно-технической и/или образовательной деятельности осуществляют производство 
сельскохозяйственной продукции, ее первичную и последующую (промышленную) переработку в соответствии с установленным перечнем.

На примере Волгоградской области базовые ставки компенсирующих субсидий на 2020 г. составляют:

- несвязная поддержка в растениеводстве (возмещение части затрат) на 1 га площади, занятой зерновыми, зернобобовыми, масличными (за исключением рапса и сои) от 177,57 руб. до 391,46 руб. (2,1-4,6 евро на га) в зависимости от района;

- поддержка в растениеводстве на 1 га площади, занятой кормовыми сельскохозяйственными культурами - 747 руб. (8,8 евро на га) на богарных землях, 3735 руб. (44 евро на га) на орошаемых землях, 6237 руб. (73 евро на га) на орошаемых землях в полупустынной зоне; овощными культурами открытого грунта - 15000 руб. (176 евро на га) для земель в полупустынной зоне и 9000 руб. (106 евро на га) для остальных территорий [Приказ от 22.01.2020 № 9];

- поддержка в молочном скотоводстве (возмещение части затрат) на 1 л реализованного или отгруженного на переработку молока - от 1,55 руб. до 3,50 руб. (1,8-4,1 евроцента на литр) в зависимости от поголовья коров и их продуктивности [Приказ от 18.03.2020 № 79].

Предполагается, что разделение субсидии на компенсирующую и стимулирующую будет способствовать рационализации государственной поддержки и выделению средств на целевые потребности регионов. Однако вопрос определения приоритетов и механизма распределения средств остается открытым. Как и любая форма поддержки, данный механизм не лишен недостатков. Риск, что распределение субсидий будет асимметричным (средства будут направлены отдельным организациям в регионах), присутствует.

Для повышения эффективности и оптимизации механизма компенсирующей и стимулирующей субсидии Министерством сельского хозяйства проводится работа по корректировке данной формы поддержки, готовится пакет изменений по упрощению процесса доведения субсидий и повышению гибкости этого механизма при сохранении действующей структуры и подхода к субсидированию.

Важным направлением господдержки является предоставление грантов на создание и развитие малых форм хозяйствования. С 2019 г. реализуется федеральный проект «Создание системы поддержки фермерства и сельской кооперации». На его финансирование предусматривается 5,3 млрд руб. (75,71 млн евро), а общий объем господдержки малых форм хозяйствования в текущем году составляет 16,3 млрд руб. (232,86 млн евро).

Основой федерального проекта стал комплекс эффективных мероприятий, способствующих развитию малого агробизнеса, в том числе дополнительные меры государственной поддержки: создание и развитие К(Ф)Х (грант «Агростартап»), создание и развитие СПоК, обеспечение деятельности и достижение показателей эффективности центров компетенций в сфере сельскохозяйственной кооперации и поддержки фермеров (см. таблицу).

Новым направлением государственной поддержки сельскохозяйственной отрасли стала реализация с 1 января 2017 г. механизма льготного кредитования агропромышленного комплекса. Коммерческие банки, принимающие участие в данном механизме, имеют право на получение субсидии (возмещение недо-

Таблиияа

Результаты финансирования и план Федерального проекта «Создание системы поддержки фермеров и развитие сельской кооперации»

\begin{tabular}{|l|c|c|c|c|c|}
\hline \multirow{2}{*}{$\begin{array}{c}\text { Меры государствен- } \\
\text { ной поддержки }\end{array}$} & \multicolumn{3}{|c|}{$\mathbf{2 0 1 9}$} & \multicolumn{2}{|c|}{$\mathbf{2 0 2 0}$ (план) } \\
\cline { 2 - 6 } & $\begin{array}{c}\text { Финансирование, } \\
\text { млрд руб. }\end{array}$ & $\begin{array}{c}\text { Число бюджето- } \\
\text { получателей }\end{array}$ & Результаты & $\begin{array}{c}\text { Финансирование, } \\
\text { млрд руб. }\end{array}$ & $\begin{array}{c}\text { Число бюджето- } \\
\text { получателей }\end{array}$ \\
\hline Грант «Агростартап» & 4,88 & 2067 К(Ф)Х & $\begin{array}{c}3304 \text { рабочих } \\
\text { мест }\end{array}$ & 3,45 & 1076 К(Ф)Х \\
\hline Субсидии СПоК & 0,55 & 237 СПоК & $\begin{array}{c}15823 \text { новых } \\
\text { членов }\end{array}$ & 0,25 & 85 СПоК \\
\hline $\begin{array}{l}\text { Субсидии Центрам } \\
\text { компетенций }\end{array}$ & 0,91 & $\begin{array}{c}83 \text { центра } \\
\text { компетенций }\end{array}$ & $\begin{array}{c}89450 \text { единиц } \\
\text { услуг }\end{array}$ & 0,12 & $\begin{array}{c}83 \text { центра } \\
\text { компетенций }\end{array}$ \\
\hline
\end{tabular}

Примечание. Составлено по: [Основные направления ...]. 


\section{УПРАВЛЕНИЕ ЭКОНОМИЧЕСКИМ РАЗВИТИЕМ}

полученных ими доходов в размере $100 \%$ ключевой ставки Банка России по кредитам, выданным по ставке не более $5 \%$ ).

С целью оценки эффективности данного механизма в 2019 г. Научно-исследовательским финансовым институтом Министерства финансов Российской Федерации проводился опрос сельскохозяйственных товаропроизводителей всех видов хозяйств с позиции его доступности, условий получения, возникающих проблем и возможных предложений по совер- шенствованию (рис. 1). Следует отметить, что такие анкеты необходимы для формирования базы запросов получателей льготного кредитования, что является основой взаимодействия агробизнеса и государства.

Респонденты, которые ответили «Нет, не эффективен» и «Скорее нет, чем да» $(25,79 \%$ от всего количества участвующих), обозначили некоторые проблемы, выступающие основанием для дальнейшего совершенствования механизма льготного кредитования (рис. 2).

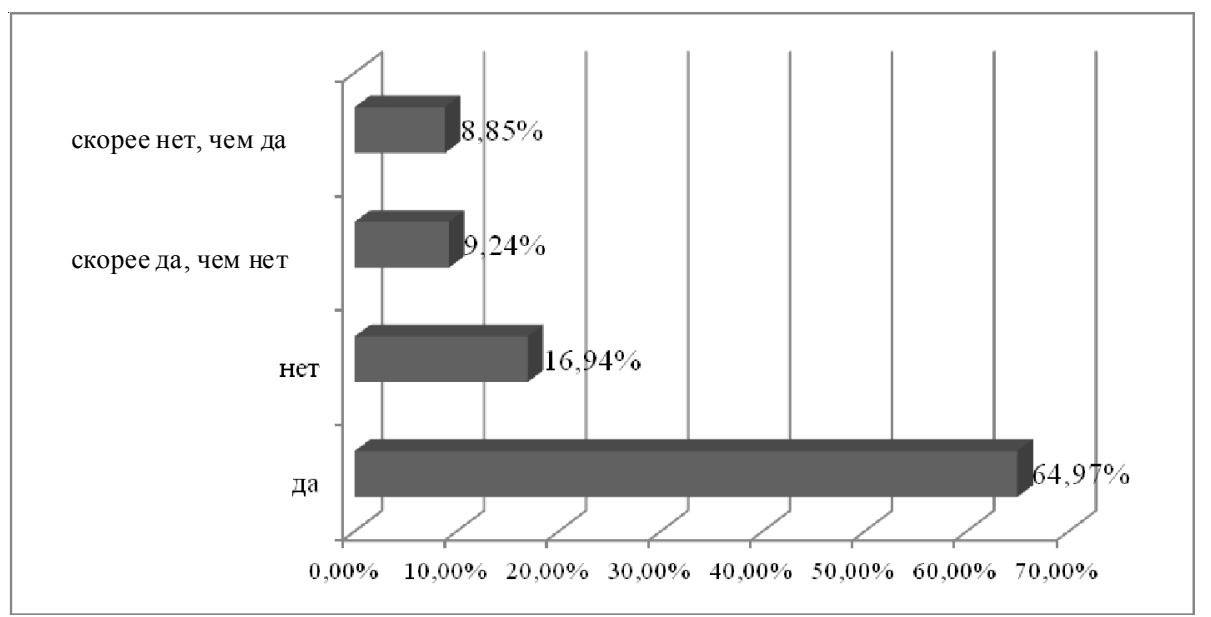

Рис. 1. Ответы респондентов об эффективности механизма льготного кредитования АПК Примечание. Составлено по: [Эффективность льготного кредитования ...].

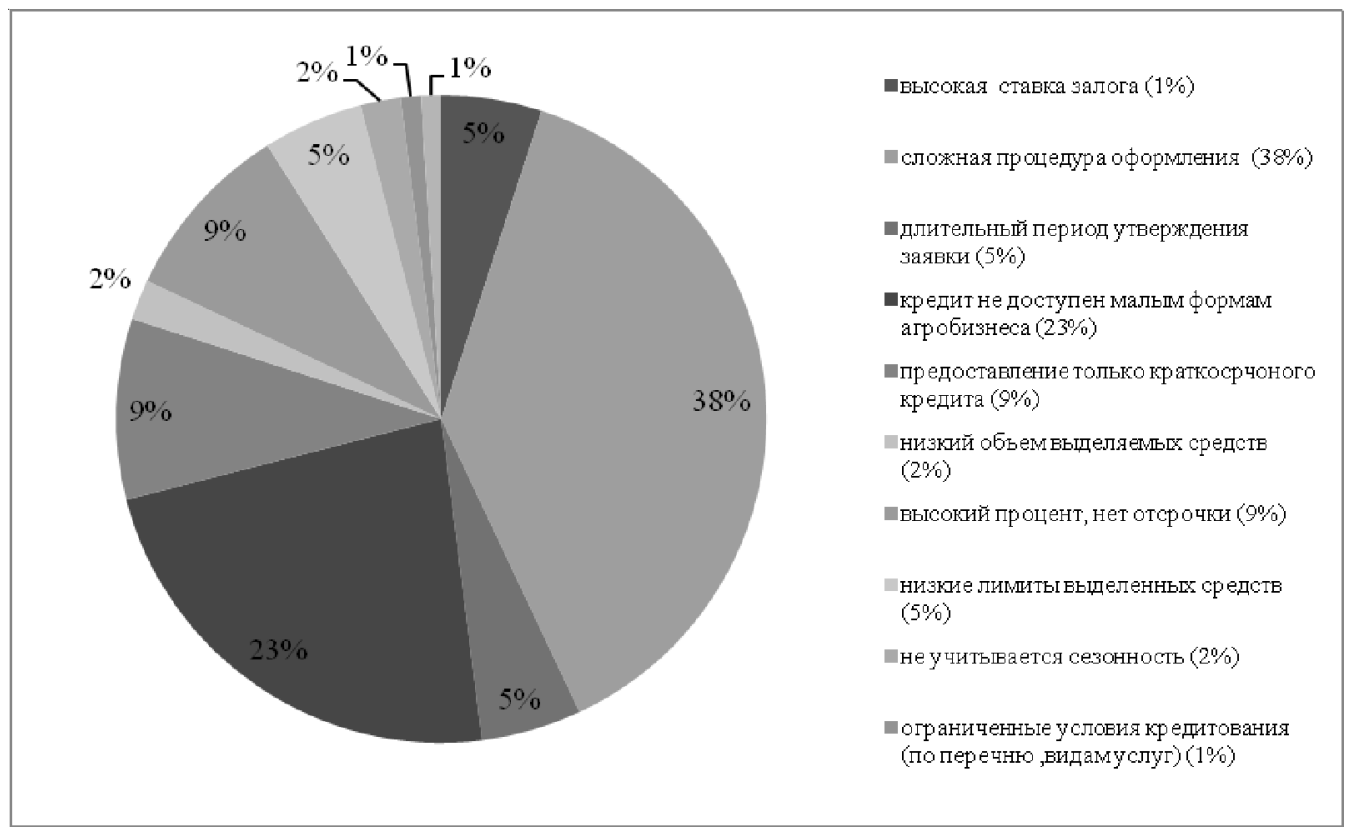

Рис. 2. Ответы респондентов на вопрос «Считаете ли Вы эффективным механизм льготного кредитования АПК?» в рамках «Нет, не эффективен» и «Скорее нет, чем да»

Примечание. Составлено по: [Эффективность льготного кредитования ...]. 
Основной проблемой, которую подтвердили 38 \% сельскохозяйственных товаропроизводителей, является сложная процедура оформления документов. Длительный период заявки отметили $5 \%$ респондентов. Зачастую такой момент в процедуре получения льготного кредита приводит к отсутствию его потребности в получении и негативным последствиям при непрерывном ведении агробизнеса. На недоступность такой формы поддержки указали $23 \%$ опрошенных.

В механизме льготного кредитования из утвержденных Министерством сельского хозяйства Российской Федерации коммерческих банков в большей степени принимают участие Россельхозбанк и ПАО Сбербанк, что ведет к снижению конкуренции [Эффективность льготного кредитования ...].

В целом механизм льготного кредитования зарекомендовал себя одним из действующих механизмов государственной поддержки сельского хозяйства.

Развитие экспорта также является перспективным направлением сельского хозяйства. Осознавая эту значимость, государство приняло и реализует Федеральный проект «Экспорт продукции АПК». По мнению представителей отрасли, субсидии являются самой важной мерой государственной поддержки, способствующей экспорту продукции (54 \%). На важность такой меры государственной поддержки, как снижение налогов и пошлин, чаще указывали представители малого и среднего агробизнеса (годовая выручка менее 2 млрд руб.) (41\%), в то время как только $14 \%$ представителей крупного бизнеса отметили значимость данной меры. Доля тех, кто подчеркивает важность создания рыночной инфраструктуры, выше среди представителей крупных компаний, нежели среди компаний малого и среднего агробизнеса (43\% против $24 \%$ соответственно) [Обзор рынка ...].

По итогам первого полугодия 2020 г. Россия поставила на внешние рынки продукции АПК общей стоимостью более 13 млрд долларов США. Это на 2 млрд долларов, или на $18 \%$, больше по сравнению с аналогичным периодом прошлого года. Ведущим покупателем отечественной продукции АПК в 2020 г. является Китай, импортировавший российского продоволь- ствия на сумму 1,9 млрд долларов, что на $35 \%$ больше, чем в первом полугодии 2019 года. На втором месте находится Турция с показателем 1,5 млрд долларов (+42 \%), на третьем - Казахстан, объем поставок в который составил 974 млн долларов (+20 \%) [Экспорт продукции АПК ...].

За первые шесть месяцев текущего года положительную динамику экспорта АПК продемонстрировали практически все основные группы товаров. Главными драйверами стали растительные масла и зерновые культуры, значительный рост зафиксирован в категориях мясной продукции и сахара. Наращиванию поставок способствуют меры государственной поддержки, направленные на стимулирование производства продукции и ее сертификацию. Министерством сельского хозяйства и другими ведомствами ведется активная работа по открытию и расширению доступа для отечественных производителей на перспективные зарубежные рынки.

По итогам 2020 г. в соответствии с паспортом федерального проекта «Экспорт продукции АПК» Россия должна экспортировать сельскохозяйственной продукции и продовольствия на 25 млрд долларов. Реализуемые меры государственной поддержки позволят достичь целевых показателей.

Механизм предоставления льготных кредитов экспортерам направлен на поддержку экспортно-ориентированных предприятий и способствует наращиванию объемов производства сельскохозяйственной продукции, востребованной на внешних рынках. В настоящее время в программе принимают участие 7 системно значимых банков, которыми выдано уже свыше 40 млрд руб. кредитных средств. Предприятия получают возможность воспользоваться кредитными средствами по льготной ставке при условии увеличения производства конкурентоспособной продукции.

Вектором современного этапа развития экономики становится ее цифровизация. По оценкам Департамента цифрового развития и управления государственными информационными ресурсами АПК Министерства сельского хозяйства России, за счет цифровизации сельского хозяйства объем рынка ИКТ в АПК должен увеличиться в ближайшие годы в 5 раз, с 400 млрд руб. в 2017 г. до 2 трлн руб. в 2024 году. С учетом потенциала и необходимости данного 
направления реализуется ведомственный проект «Цифровое сельское хозяйство».

Применение цифровых технологий способствует функционированию и повышению эффективности сельского хозяйства (см. об этом: [Трендов и др., 2019]) Так, использование мобильных приложений позволит сельскохозяйственным товаропроизводителям получать информацию о ценах, сократит случаи нарушения рыночного равновесия и обеспечит планирование производственных процессов. Способность современных технологий заключается в своевременном реагировании на вспышки болезней и вредителей, неурожай, климатические изменения; аграрии, получив оповещения, заблаговременно изменят свои действия с учетом прогноза погоды. Программное обеспечение играет значимую роль в отрасли, направлено на планирование ресурсов сельскохозяйственных товаропроизводителей, способствует оптимизации процесса от закупок до производства и сбыта, позволяет реагировать на проблемы связанные с охраной окружающей среды и т. д.

Цифровые технологии, основой которых выступает искусственный интеллект, способствуют повышению эффективности управления агробизнесом. С помощью таких технологий, не требуя физического присутствия самого фермера, осуществляется оценка состояния поля и мониторинг за каждым этапом производственного цикла, оптимизация использования ресурсов.

Сельскохозяйственные роботы («агроботы») в ближайшее время окажут сильное воздействие на сельское хозяйство. Их возможности заключаются в измерении расходов воды, оптимизации полива.

Перечисленные преимущества применения цифровых технологий сдерживаются проблемами, среди которых можно выделить ключевые:

- недостаточность или полное отсутствие финансовых средств у большинства сельскохозяйственных производителей для внедрения ИКТ;

- дефицит квалифицированных кадров;

- недостаточное развитие цифровой инфраструктуры в сельской местности;

- низкая информированность о возможностях цифровых технологий;
- неопределенность правового статуса, недостаточное финансирование на всех уровнях (федеральном, региональном и местном), слабое кадровое обеспечение, отсутствие единых информационных баз, низкая информативность сайтов информационно-консультационных служб;

- высокая импортозависимость (отсутствие производства необходимого количества средств Интернета вещей российского производства).

\section{Угрозы и возможности \\ развития сельского хозяйства \\ в условиях стресс-факторов: последствия пандемии COVID-19}

Достаточно сложно оценить последствия пандемии в силу необычности такого кризиca, однако сделать некоторые выводы и дать прогнозы развития сельского хозяйства в этих условиях предоставляется возможным. Отрасль ориентирована на базовые потребности, и в этом заключается преимущество в кризисный период.

АПК не затронул продолжительный период нерабочих дней, введенный с целью борьбы с пандемией, и он не был официально признан сектором экономики, пострадавшим от COVID-19. Однако, по оценке Национального рейтингового агентства, добавленная стоимость в сельском и лесном хозяйстве, рыболовстве и рыбоводстве из-за режима самоизоляции в 2020 г. сократится на 5,1 \% [Последствия пандемии ...].

Воздействие COVID-19 на отрасль выразилось прежде всего в необходимости перестройки всех производственных и обеспечивающих процессов так, чтобы не допустить распространение вируса на предприятиях. Последние несут дополнительные издержки на профилактические мероприятия (дезинфекция, средства защиты для сотрудников и т. д.). Расходы средних и крупных представителей агробизнеса в условиях пандемии достигли десятки миллионов рублей в месяц.

Связанное с коронавирусом закрытие границ привело к перестройке логистических цепочек. Это поставило под угрозу поставки средств производства, которые в свою очередь являются жизненно важны- 
ми (семяна, средства защиты растений, кормовые добавки, пищевые ингредиенты и т. п). По данным Министерства сельского хозяйства, доля иностранных кормовых добавок по отдельным позициям достигает $100 \%$. В валовом объеме используемых семян доля российских составляет всего $20 \%$. Долю импортной продукции на рынке ветеринарных препаратов эксперты оценивают в целом на уровне 60-65 \%. Ограничения на передвижение между странами сделало невозможным оперативное привлечение зарубежных инженерно-технических специалистов, что негативно повлияло на темпы монтажа и пуско-наладочные работы для ряда крупных проектов АПК («Мираторг», «Черкизово», «Белая дача», «Русагро», «Умалат»). Не менее значимой проблемой стало обеспечение сезонным персоналом, потребность в котором составляет до 500 тыс. чел. [Последствия пандемии ...; Пандемия коронавируса и экономический кризис ...].

Пандемия нарушила товаропроводящую сеть, в особенности это коснулось малых и средних форм агробизнеса. Крестьянские (фермерские) хозяйства традиционно реализовывали свою продукцию на небольших ярмарках, нестационарных торговых точках, которые оказались закрыты [Бизнес в эпоху коронавируса ...].

Пандемия оказала влияние и на органическое сельское хозяйство. С одной стороны, спрос на органические продукты питания за период самоизоляции вырос на 15-20 \% в сравнении с аналогичным периодом прошлого года. По окончании пандемии тренд на органическую и в целом более здоровую продукцию закрепится и будет способствовать росту органического производства [Существенного падения ...].

С другой стороны, органическая продукция нацелена на потребителя с достатком средним и выше среднего, а в период экономического кризиса падает покупательная способность населения. Граждане, сохранившие свои доходы, стараются увеличить сбережения и сократить траты. Данный фактор окажет тормозящее воздействие на развитие экосектора.

В связи с этим производители и переработчики органической продукции отмечают необходимость специальных мер поддержки, чтобы выровнять условия, при которых работают представители классического сельского хозяйства и органического производства. К таковым могут быть отнесены дотации производителям органики на сертификацию, закупку биопрепаратов и биоудобрений, увеличенная погектарная поддержка и поддержка на литр молока, особенно в период конверсии, развитие переработки органической продукции [Последствия пандемии ...]

Во время пандемии, по результатам проведенного президентом Российской Федерации отдельного совещания, посвященного текущей ситуации в сельском хозяйстве и пищевой промышленности, было принято решение об усилении мер государственной поддержки на фоне коронавирусного кризиса. Эти меры прописаны в проекте Общенационального плана действий, направленного на восстановление занятости и доходов населения, рост экономики и долгосрочные структурные изменения на 2020-2021 гг.:

- докапитализация Росагролизинга (6 млрд руб.);

- субсидирование тарифов на перевозку овощной продукции, минеральных удобрений, продуктов переработки семян масличных культур для субъектов ДФО (1 млрд руб.);

- пролонгация на срок до 1 года действующих краткосрочных кредитов и отсрочки по выплате основного долга и процентов, приходящихся на 2020 г. по ранее заключенным льготным инвестиционным кредитам, увеличение объемов льготного кредитования сельскохозяйственных производителей и предприятий пищевой промышленности (4 млрд руб.);

- создание единой цифровой платформы выявления, оценки и ввода в сельскохозяйственный оборот земель сельскохозяйственного назначения, включающее инвестиционную интернет-площадку, на которой потенциальный инвестор в сфере АПК сможет получить готовое решение по ведению сельскохозяйственной деятельности, наиболее востребованной в соответствующем регионе (1,5 млрд руб).

\section{Заключение}

Аграриям предстоит большая работа по преодолению последствий кризиса и восстановлению рынка. В таких условиях роль госу- 
дарства в развитии сельского хозяйства становится крайне важной и необходимой. Отрасли потребуется поддержка банковского сектора в предоставлении особых условий кредитования и увеличение ее финансирования. Необходимо также поддержание роста покупательской способности, так как стагнация доходов населения в целом тормозит развитие отрасли.

В условиях пандемии не исключена возможность переформатирования федерального проекта «Экспорт продукции АПК». Это обусловлено современными вызовами: снижением емкости мирового рынка, падением платежеспособного спроса, обострением конкуренции [Последствия пандемии ...].

Принятый механизм льготного кредитования сельского хозяйства позволил повысить доступность кредитования и снизить финансовую нагрузку на сельскохозяйственных товаропроизводителей. Целесообразно продолжать его совершенствовать: пересмотреть возможности выдачи кредитов малым формам хозяйствования, ввести отсрочки платежей в силу сезонности отрасли. Представляется возможным, учитывая современные условия, расширить перечень целевого использования средств по данному механизму (внедрение и сопровождение технологического оборудования для цифрового сельского хозяйства, российских организаций, разрабатывающих и внедряющих цифровые платформы и программные продукты на предприятиях данной отрасли).

Учитывая возрастающую роль качественного доступа в Интернет по мере продолжения цифровизации, пандемия COVID-19 дала мощный импульс к принятию новых мер по ликвидации «цифрового разрыва» в форме государственных инвестиций в инфраструктуру, а также вызвала всплеск программ по увеличению количества подключений и распространению устройств для доступа в Интернет.

Одной из важнейших задач по стимулированию цифровой трансформации сельского хозяйства является подготовка и повышение квалификации кадров. Представляется необходимым разработка и внедрение новых образовательных программ, дисциплин и курсов по цифровой сельской экономике, разработка соответствующих учебников и пособий, орга- низация тематических семинаров и вебинаров и т. п. В первую очередь необходима подготовка специалистов в сфере Интернета вещей, управления беспилотными летательными аппаратами (дронами), точного земледелия, роботизации производства и т. п. Для стимулирования деятельности ИКТ-компаний, работающих в отдаленных сельских районах, представляется необходимым выделение соответствующих целевых субсидий.

\section{СПИСОК ЛИТЕРАТУРЫ}

Агроэкспорт 2030: тренды и перспективы // Официальный сайт Министерства сельского хозяйства Российской Федерации. - Электрон. текстовые дан. - Режим доступа: https:// mcx.gov.ru/ministry/departments/departamentinformatsionnoy-politiki-i-spetsialnykhproektov/news/eksport-produktsii-apk-v-ipolugodii-uvelichilsya-na-18-i-prevysil-13-mlrddollarov. - Загл. с экрана.

Бизнес в эпоху коронавируса: российские фермеры теряют клиентов. - Электрон. текстовые дан. Режим доступа: https://www.dairynews.ru/ news/biznes-v-epokhu-koronavirusa-rossiyskiefermery-te.html. - Загл. с экрана.

Минпромторг России запустил программу субсидирования скидок на пищевое оборудование // Официальный сайт Министерства промышленности и торговли. - Электрон. текстовые дан.Режим доступа: https://minpromtorg.gov.ru/ press-centre/news/\#!minpromtorg_rossii_ zapustil_programmu_subsidirovaniya_skidok_ na_pishhevoe_oborudovanie. - Загл. с экрана.

Обзор рынка сельского хозяйства. - 2019. - Электрон. текстовые дан. - Режим доступа: https://ru.investinrussia.com/data/file/obzorrynka-selskogo-hozyajstva-2019.pdf. - Загл. с экрана.

Основные направления социально-экономического развития сельских территорий в Российской Федерации. Аналитическая работа кооперационного проекта «Германо-Российский аграрно-политический диалог» (Москва Берлин, апрель 2020). - Электрон. текстовые дан. - Режим доступа: https://agrardialog.ru/ files/prints/2020_sqa_landliche_entwicklung aw_petrikow_rus.pdf. - Загл. с экрана.

Пандемия коронавируса и экономический кризис приведут к падению ВВП РФ. - Электрон. текстовые дан. - Режим доступа: https://www. dairynews.ru/news/pandemiya-koronavirusa-vsovokupnosti-privedut-k-p.html. - Загл. с экрана. 
Последствия пандемии для сельского хозяйства и аграрных рынков РФ. Государственные меры по стабилизации ситуации // Германо-Российский аграрно-политический диалог. - Электрон. текстовые дан. - Режим доступа: https:// agrardialog.ru/prints/details/id/241. - Загл. с экрана.

Приказ комитета сельского хозяйства Волгоградской области от 18.03.2020 № 79 «Об утверждении Порядка определения ставок для расчета размера субсидий на возмещение части затрат на 1 килограмм реализованного и (или) отгруженного на собственную переработку молока». - Доступ из информ.-правового портала «Гарант.ру».

Приказ комитета сельского хозяйства Волгоградской области от 22.01.2020 № 9 «Об утверждении ставок для расчета размера субсидии на возмещение части затрат на 1 гектар посевной площади сельскохозяйственных культур». - Доступ из информ.-правового портала «Гарант.ру».

Распределение субсидий бюджетам субъектов Российской Федерации на поддержку сельскохозяйственного производства по отдельным подотраслям растениеводства и животноводства на 2020 год и на плановый период 2021 и 2022 годов. - Доступ из информ.-правового портала «КонсультантПлюс».

Совещание о ситуации в сельском хозяйстве и пищевой промышленности. - Электрон. текстовые дан. - Режим доступа: http://www.kremlin.ru/ events/president/news/63371. - Загл. с экрана.

Существенного падения потребления продуктов питания не наблюдается // Аналитический Центр при Правительстве Российской Федерации. Электрон. текстовые дан. - Режим доступа: https://ac.gov.ru/news/page/susestvennogopadenia-potreblenia-produktov-pitania-nenabludaetsa-26632. - Загл. с экрана.

Трендов, Н. М. Цифровые технологии на службе сельского хозяйства и сельских районов справочный документ / Н. М. Трендов, С. Варас, М. Цзэн. - Рим : Продовольств. и с.-х. ООН, 2019. - Электрон. текстовые дан. - Режим доступа: http://www.fao.org/3/ca4887ru/ca4887ru. pdf. - Загл. с экрана.

Экспорт продукции АПК в I полугодии увеличился на 18 \% и превысил 13 млрд долларов // Официальный сайт Министерства сельского хозяйства Российской Федерации. - Электрон. текстовые дан. - Режим доступа: https://mcx.gov.ru/ministry/ departments/departament-informatsionnoypolitiki-i-spetsialnykh-proektov/news/eksportproduktsii-apk-v-i-polugodii-uvelichilsya-na-18-iprevysil-13-mlrd-dollarov. - Загл. с экрана.
Эффективность льготного кредитования сельхозтоваропроизводителей агропромышленного комплекса (на основе опроса) // Официальный сайт Научно-исследовательского финансового института Министерства финансов Российской Федерации. - Электрон. текстовые дан. Режим доступа: https://nifi.ru/images/FILES/ Reports/Ligot_kreditovanie_opros.pdf. - Загл. с экрана.

\section{REFERENCES}

Agroeksport 2030: trendy i perspektivy [Agroexport 2030: trends and prospects]. Ofitsialnyy sayt Ministerstva selskogo khozyaystva Rossiyskoy Federatsii [Official Website of the Ministry of Agriculture of the Russian Federation]. URL: https://mcx.gov.ru/ministry/departments/ departament-informatsionnoy-politiki-ispetsialnykh-proektov/news/eksportproduktsii-apk-v-i-polugodii-uvelichilsya-na-18i-prevysil-13-mlrd-dollarov/.

Biznes v epokhu koronavirusa: rossiyskie fermery teryayut klientov [Business in the Era of Coronavirus: Russian Farmers Lose Customers]. URL: https://www.dairynews.ru/news/biznes-vepokhu-koronavirusa-rossiyskie-fermery-te.html.

Minpromtorg Rossii zapustil programmu subsidirovaniya skidok na pishchevoe oborudovanie [The Ministry of Industry and Trade of Russia Launched a Program to Subsidize Discounts on Food Equipment]. Ofitsialnyy sayt Ministerstva promyshlennosti $i$ torgovli [Official Website of the Ministry of Industry and Trade]. URL: https://minpromtorg.gov.ru/presscentre/news/\#!minpromtorg_rossii_zapustil_ programmu_subsidirovaniya_skidok_na_pishhevoe_ oborudovanie.

Obzor rynka selskogo khozyaystva [Agricultural Market Overview]. 2019. URL: https:// ru.investinrussia.com/data/file/obzor-rynkaselskogo-hozyajstva-2019.pdf.

Osnovnye napravleniya sotsialno-ekonomicheskogo razvitiya selskikh territoriy $v$ Rossiyskoy Federatsii. Analiticheskaya rabota kooperatsionnogo proekta "GermanoRossiyskiy agrarno-politicheskiy dialog» (Moskva-Berlin, aprel 2020) [Main Directions of Socio-Economic Development of Rural Territories in the Russian Federation. Analytical Work of the Cooperative Project "GermanRussian Agrarian-Political Dialogue" (MoscowBerlin, April 2020)]. URL: https://agrardialog.ru/ files/prints/2020_sqa_landliche_entwicklung_ aw_petrikow_rus.pdf. 
Pandemiya koronavirusa i ekonomicheskiy krizis privedut $k$ padeniyu VVP RF [The Pandemic of Coronavirus and the Economic Crisis Will Lead to the Fall of the Gross Domestic Product of the Russian Federation]. URL: https://www. dairynews.ru/news/pandemiya-koronavirusa-vsovokupnosti-privedut-k-p.html.

Posledstviya pandemii dlya selskogo khozyaystva i agrarnykh rynkov RF. Gosudarstvennye mery po stabilizatsii situatsii [The Consequences of the Pandemic for Agriculture and Agricultural Markets of the Russian Federation. State Measures to Stabilize the Situation]. GermanoRossiyskiy agrarno-politicheskiy dialog [German-Russian Agrarian-Political Dialogue]. URL: https://agrardialog.ru/prints/details/id/241.

Prikaz komiteta selskogo khozyaystva Volgogradskoy oblasti ot 18.03.2020 № 79 «Ob utverzhdenii Poryadka opredeleniya stavok dlya rascheta razmera subsidiy na vozmeshchenie chasti zatrat na 1 kilogramm realizovannogo i (ili) otgruzhennogo na sobstvennuyu pererabotku moloka» [Order of the Committee of Agriculture of Volgograd Region no. 79 Dated March 18, 2020 "On the Approval of the Procedure for Determining Rates for Calculating the Amount of Subsidies for the Reimbursement of a Part of the Costs per 1 Kilogram of Milk Sold and/or Shipped for Own Processing"]. Access from "Garant" informational and legal web portal.

Prikaz komiteta selskogo khozyaystva Volgogradskoy oblasti ot 22.01.2020 № 9 «Ob utverzhdenii stavok dlya rascheta razmera subsidii na vozmeshchenie chasti zatrat na 1 gektar posevnoy ploshchadi selskokhozyaystvennykh kultur» [Order of the Committee of Agriculture of Volgograd Region no. 9 Dated January 22, 2020 "On the Approval of Rates for Calculating the Amount of the Subsidy for the Reimbursement of a Part of the Costs Per 1 Hectare of Planted Area of Crops"]. Access from "Garant" informational and legal web portal.

Raspredelenie subsidiy byudzhetam subyektov Rossiyskoy Federatsii na podderzhku selskokhozyaystvennogo proizvodstva po otdelnym podotraslyam rastenievodstva i zhivotnovodstva na 2020 god i na planovyy period 2021 i 2022 godov [Allocation of Subsidies to the Budgets of the Constituent Entities of the Russian Federation for Supporting Agricultural Production by
Individual Sub-Sectors of Crop and Livestock Production for 2020 and for the Planning Period of 2021 and 2022]. Access from Reference Legal System "KonsultantPlyus".

Soveshchanie o situatsii $v$ selskom khozyaystve $i$ pishchevoy promyshlennosti [Meeting on the Situation in Agriculture and the Food Industry]. URL: http://www.kremlin.ru/events/president/ news/63371.

Sushchestvennogo padeniya potrebleniya produktov pitaniya ne nablyudaetsya [There Is No Significant Drop in Food Consumption]. Analiticheskiy Tsentr pri Pravitelstve Rossiyskoy Federatsii [Analytical Center Under the Government of the Russian Federation]. URL: https://ac.gov.ru/news/page/susestvennogopadenia-potreblenia-produktov-pitania-nenabludaetsa-26632.

Trendov N.M., Varas S., Czen M. Tsifrovye tekhnologii na sluzhbe selskogo khozyaystva i selskikh rayonov spravochnyy dokument [Digital Technologies for Agriculture and Rural Services. Background Paper]. Rim, Prodovolstvennaya i selskokhozyaystvennaya organizatsiya Obyedinennykh Natsiy, 2019. URL: http://www. fao.org/3/ca4887ru/ca4887ru.pdf.

Eksport produktsii APK v I polugodii uvelichilsya na $18 \%$ i prevysil 13 mlrd dollarov [Exports of Agricultural Products in the First Half of the Year Increased by $18 \%$ and Exceeded $\$ 13$ Billion]. Ofitsialnyy sayt Ministerstva selskogo khozyaystva Rossiyskoy Federatsii [Official Website of the Ministry of Agriculture of the Russian Federation]. URL: https://mcx.gov.ru/ ministry/departments/departamentinformatsionnoy-politiki-i-spetsialnykhproektov/news/eksport-produktsii-apk-v-ipolugodii-uvelichilsya-na-18-i-prevysil-13-mlrddollarov/.

Effektivnost lgotnogo kreditovaniya selkhoztovaroproizvoditeley agropromyshlennogo kompleksa (na osnove oprosa) [Efficiency of Concessional Lending to Agricultural Producers of the AgroIndustrial Complex (Based on a Survey). Ofitsialnyy sayt Nauchno-issledovatelskogo finansovogo instituta Ministerstva finansov Rossiyskoy Federatsii [Official Website of the Research Financial Institute of the Ministry of Finance of the Russian Federation]. URL: https:/ /nifi.ru/images/FILES/Reports/Ligot_ kreditovanie_opros.pdf. 


\section{Information About the Authors}

Natalya V. Gorshkova, Doctor of Sciences (Economics), Associate Professor, Head of the Department of the Theory of Finance, Credit and Taxation, Volgograd State University, Prosp. Universitetsky, 100, 400062 Volgograd, Russian Federation, gorshkovanv@volsu.ru, https://orcid.org/0000-0003-0586-9509

Ekaterina A. Shkarupa, Candidate of Sciences (Economics), Associate Professor, Department of the Theory of Finance, Credit and Taxation, Volgograd State University, Prosp. Universitetsky, 100, 400062 Volgograd, Russian Federation, shkarupaea@volsu.ru, https://orcid.org/0000-0002-9986-2641

Aleksandr S. Rulev, Doctor of Sciences (Agriculture), Professor, Academician of the Russian Academy of Sciences, Chief Researcher, Institute of Natural Sciences, Volgograd State University, Prosp. Universitetsky, 100, 400062 Volgograd, Russian Federation, rylev@volsu.ru, https://orcid.org/0000-0001-6152-288X

\section{Информация об авторе}

Наталья Валерьевна Горшкова, доктор экономических наук, доцент, заведующая кафедрой теории финансов, кредита и налогообложения, Волгоградский государственный университет, просп. Университетский, 100, 400062 г. Волгоград, Российская Федерация, gorshkovanv@volsu.ru, https://orcid.org/0000-0003-0586-9509

Екатерина Александровна Шкарупа, кандидат экономических наук, доцент кафедры теории финансов, кредита и налогообложения, Волгоградский государственный университет, просп. Университетский, 100, 400062 г. Волгоград, Российская Федерация, shkarupaea@volsu.ru, https://orcid.org/0000-0002-9986-2641

Александр Сергеевич Рулев, доктор сельскохозяйственных наук, профессор, академик PAН, главный научный сотрудник института естественных наук, Волгоградский государственный университет, просп. Университетский, 100, 400062 г. Волгоград, Российская Федерация, rylev@volsu.ru, https://orcid.org/0000-0001-6152-288X 